\title{
Minat Siswa Dalam Mengikuti Pembelajaran Pendidikan Jasmani Olahraga Dan Kesehatan
}

\author{
Student Interest In Following The Learning Of \\ Sports And Health Education
}

\author{
Sri Widaningsih ${ }^{1}$, Ilham Taupik Muhamad Hendarmin² \\ 1,2STKIP Pasundan, Cimahi, Jawa Barat, Indonesia \\ Wrrik.bun79@gmail.com
}

\begin{abstract}
Abstrak
Penelitian ini adalah proses siswa dalam pembelajaran pendidikan jasmani olahraga dan kesehatan memilikirasa tidak tertarik dan kurang perhatian sehingga untuk memperoleh pengetahuan siswa dalam pembelajaran tersebut belum tercapai. penelitian ini bertujuan untuk mengetahui bes arnya minat sisw a sma al-aziz islamic boarding school terhadap pembelajaran pendidikan jasmani olahraga dan kesehatan. penelitain ini merupakan jenis penelitian deskriptif kuantitatif dengan metode survei. teknik pengumpulan data ini menggunakan angket yang terdiri dari 37 butir pernyataan. subjek penelitian ini adalah siswa sma al-aziz islamic boarding school. teknik analisis data ini adalah deskriptif dengan menggunakan presentase menggunakan bantuan program komputer microsoft excel dan spss. dari hasil penelitain yang telah dilakukan, bahwa minat siswa sma al-aziz islamic boarding school terhadap pembelajaran pendidikan jasmani olahraga dan kesehatan didapat dari 45 responden yang menunjukan bahwa 35,55\% dengan kategori tinggi, 40\% dengan kategori sedang, olahraga dan kesehatan sma al-aziz islamic boarding school berada di kategori sedang.
\end{abstract}

Kata Kunci: Minat, Pembelajaran Pendidikan jasmani Olahraga dan Kesehatan

\begin{abstract}
This research is the process of students in the learning of physical education sports and health has a sense of disinterest and inconse concern so to acquire the knowledge of students in the learning has not been achieved. This study aims to find out the huge interest of al-AZIZ ISLAMIC BOARDING SCHOOL high school students towards physical education learning sports and health. This research is a type of quantitative descriptive research with survey methods. This data collection technique uses a questionnaire consisting of 37 statement items. The subject of this study was a student of AL-AZIZ ISLAMIC BOARDING SCHOOL. This data analysis technique is descriptive by using percentages using the help of microsoft excel and SPSS computer programs. From the results of research that has been done, that the interest of high school students Al-Aziz Islamic Boarding School to the learning of physical education sports and health obtained from 45 respondents who showed that 35.55\% with a high category, $40 \%$ with a moderate category, sports and health Al-Aziz Islamic Boarding School is in the moderate category.
\end{abstract}

Keywords: Interests, Learning Physical Education Sports and Health 


\section{PENDAHULUAN}

Pendidikan Jasmani, VO2Max adalah volume maksimal O2 yang di proses oleh tubuh manusia pada saat melakukan kegiatan yang intensif. Volume vo2max ini adalah suatu tingkatan kemampuan tubuh yang dinyatakan dalam liter per menit.Untuk menjadi atlet futsal dibutuhkan VO2Max yang baik karna pertandinganya berlangsung dalam waktu yang lama dan intensitas yang tinggi sehingga memerlukan daya tahan yang tinggi VO2Max di pengaruhi salah satunya yaitu usia. VO2max adalah kecepatan pemakaian oksigen dalam metabolisme aerob maksimum. Kapasitas aerobik maksimal sangat erat hubungannya dengan fungsi dari sistem paru - jantung yang terdiri atas paru, jantung, sistem pembuluh darah serta darah yang satu sama lain saling berhubungan dan saling menunjang dalam menyampaikan oksigen otot yang sedang bekerja dan mengangkut limbah dari otot tersebut. Manfaat vo2max mengacu pada jumlah maksimum oksigen yang dapat dimanfaatan selama berolahraga pada tingkat tertentu. Biasanya digunakan untuk mengetahui daya tahan aerobik mempertahankan kecepatan atau kebugaran kardiovaskular seorang atlet sebelum dan di akhir siklus pelatihan.

Pada remaja usia 13-19 tahun, berdasarkan PAP (penilaian acuan patokan) nilai VO2Max berada antara 35,0-55,9 ml/kg/menit (nurhasan, 2002). Hal ini dikuatkan beberapa penelitian yang menunjukan VO2Max remaja berada pada kategori rendah yaitu pada penelitian VO2Max ektrakurikuler Futsal. Permainan futsal adalah salah satu cabanng olahraga dinamis yang membutuhkan konidisi fisik prima. Fisik yang prima adalah syarat dasar yang harus dimiliki seorang pemain futsal, karna dalam permainan futsal di tuntut untuk berlari setiap saaat untuk mengejar, menggiring, merebut bola dari lawan, bergerak kesegalah arah dengan cepat, menggerakan kaki dan tangan serta kepala dengan tepat dan melompat dengan tepat. Kondisi pisik memegang peranan yang sangat penting dalam upaya terjun kedunia profesional, karna kondisi fisik dianggap sebagai faktor dasar bagi seorang atlet sepakbola untuk bertanding dengan baik. Kondisi fisik prima dalam permainan futsal menunjukan adanya penggunaan sistem energi tubuh.

Futsal merupakan permianan olahraga yang memprioritaskan kemampuan daya tahan aerobik yang baik karna para pemainya banyak melakukan sprint berkali kali untuk melakukan serangan,merebut bola maupun berlari untuk mengamankan daerahnya sehingga membutuhkan system aerobik yang baik. System energy aerobik salah satunya adalaah penggunaan oksigen tubuh secara maksimal permenit atau disebutVo2max Berdasarkan fenomena diatas peneliti mempunyai inisiatif untuk melakukan penelitian terhadap peserta ektrakurikuler futsal di SMAN 1 Parongpong. Berdasarkan pengamatan yang sudah dilakukan peserta cepat merasakan kelelahan ketika melakukan 
aktivitas olahraga futsal. VO2Max dilakukan untuk mengetahui daya tahan jantung yang juga merupakan faktor utama dalam kebugaran jasmani yang dibutuhkan oleh atlet, sehingga atlet futsal yang mempunyai VO2Max yang tinggi akan memiliki kemampuan daya tahan yang baik pula.VO2Max dapat diukur dengan menggunakan beberapa cara diantaranya (a) metode balke (b) cooper test (c) fartlek dan (d)multi stage. Pada penelitian ini pengukuran Vo2max dilakukan dengan cara test multi stage atau bleep test. Bleep test adalah salah satu test lapangan yang populer digunakan untuk mencari nilai perkiraan VO2Max (Herita, 2017). Berdasarkan hasil paparan diatas peneliti disini berfokus pada pengukuran tingkat VO2Max pemain futsal di SMAN 1 Parongpong sehingga judul penelitian ini adalah "Survei Tingkat VO2Max siswa Ektrakurikuler Futsal".

\section{METODE}

Metode Metode Penelitian yang penulis lakukan menggunakan metode penelitian deskriptif kuantitatif. Metode deskriptif adalah suatu metode dalam meneliti status kelompok manusia, suatu objek, suatu set kondisi, suatu sistem pemikiran, ataupun suatu kelas peristiw a pada masa sekarang. Metode deskrptif adalah pencarian fakta dengan interpensi yang tepat . dalam penelitian ini peneliti mengunakan metode deskriptip dengan rancangan survei (M.Nazir Ph.D, 1997). Populasi dalam penelitian ini adalah seluruh anggota ektrakurikuler futsal SMAN 1 Parongpong yang berjumlah 15 orang yang berjenis kelamin laki laki, usia sekitar antara 15 - 17 tahun. Teknik Sampling dalam menentukan sampel, peneliti menggunakan Teknik Sampling Jenuh atau Total Sampling. Maka Sampel dalam penelitian ini adalah seluruh siswa ektrakurikuler futsal SMAN 1 Parongpong yang berjumlah 15 orang.

\section{HASIL DAN PEMBAHASAN}

\section{Hasil}

Deskripsi data penelitian Pengukuran ketahanan daya tahan aerobic (VO2Max) dalam penelitian ini ditujukan kepada siswa SMAN 1 Parongpong yang mengikuti ekstrakurikuler Futsal. Adapun hasil dari Survei pengukuran tersebut dapat dilihat pada table di bawah ini:

Berdasarkan hasil pengukuran diatas, dapat diketahui tingkat pengukuran VO2Max siswa ektrakurikuler Futsal di SMAN 1 Parongpong berada pada kategori Kurang (K) dan cukup (C). persentase sec ara keseluruhan dapat dilihat pada table berikut: 


\section{Tabel 1. Hasil Pengukuran VO2Max sis wa Ektrakurikuler Futsal}

\begin{tabular}{cccccc}
\hline Responden & Usia & Iahap & 3alikan & VO2Max & Kategori \\
\hline 1 & 16 & 9 & 2 & 43,9 & $\mathrm{C}$ \\
2 & 17 & 4 & 4 & 27,6 & $\mathrm{~K}$ \\
3 & 17 & 5 & 9 & 32,9 & $\mathrm{~K}$ \\
4 & 16 & 8 & 1 & 40,2 & $\mathrm{C}$ \\
5 & 17 & 6 & 2 & 33,6 & $\mathrm{~K}$ \\
6 & 18 & 7 & 9 & 39,5 & $\mathrm{C}$ \\
7 & 16 & 8 & 10 & 43 & $\mathrm{C}$ \\
8 & 17 & 5 & 4 & 31 & $\mathrm{~K}$ \\
9 & 17 & 8 & 2 & 40,5 & $\mathrm{C}$ \\
10 & 16 & 5 & 6 & 31,8 & $\mathrm{~K}$ \\
11 & 17 & 7 & 3 & 37,4 & $\mathrm{C}$ \\
12 & 16 & 8 & 1 & 40,2 & $\mathrm{C}$ \\
13 & 16 & 8 & 1 & 40,2 & $\mathrm{C}$ \\
14 & 16 & 6 & 10 & 36,4 & $\mathrm{C}$ \\
15 & 17 & 6 & 4 & 34,3 & $\mathrm{~K}$ \\
& \multicolumn{2}{c}{ Jumlah } & & 552,5 & \\
& Rata - Rata (mean) & & 36,83 & $\mathrm{C}$ \\
& Skor tertinggi & & 43,9 & $\mathrm{C}$ \\
& Skor terendah & & 27,6 & $\mathrm{~K}$ \\
\hline
\end{tabular}

Tabel 2. Persentase Pengukuran VO2Max Siswa Ektrakurikuler Futsal

\begin{tabular}{lll}
\hline Kategori & Jumlah & Persentase \\
\hline Kurang & 6 & $40 \%$ \\
Cukup & 9 & $60 \%$ \\
Baik & 0 & $0 \%$ \\
Baik sekali & 0 & $0 \%$ \\
Sempurna & 0 & $0 \%$ \\
N & 15 & $100 \%$ \\
\hline
\end{tabular}

Pada tabel 2 dapat kita lihat bahw a hasil pengukuran VO2Max sec ara keseluruhan pada Ektrakurikuler Futsal SMAN 1 Parongpong sebagian besar yaitu $40 \%$ berada pada kategori Kurang dan sebagian lagi dalam kategoriCukup dengan persentase sebesar $60 \%$. Dan dari data yang diperoleh tidak ada yang menghasilkan dalam kategori Baik, Baik seklai, dan Sempurna dengan persentase $0 \%$.

\section{Pembahas an}

Penelitian ini Permainan Futsal merupakan olahraga yang berdurasikan 20 x 2 menit. Jika selama bertanding pemain atau tim bisa mengatur Irama permainan,kemungkinan besar pemain tersebut akan bias dimenangkan . karna itu selain penguasaan tehnik dan taktik, unsur fisik merupakan komponen yang penting untuk atlit khususnya. Sarjdono (1976) menyatakan bahwa unsur unsur Kondisi fisik yang penting perlu dikembangkan dalam permainan futsal antara lain: kekuatan (strength), daya tahan otot (endurance), daya ledak (power) kecepatan (speed) dan daya tahan paru jantung. Kebugaran aerobic adalah suatu aktivitas yang menekankan pada kemampuan tubuh dalam 
melakukan aktivitas pekerjaan dalam waktu yang lama dan tidak mengalami kelelahan yang berlebih .(Suharjana, 2014). Daya tahan kardioresperasi adalah kemampuan melakukan aktivitas berat dan berlangsung yang lama tergantung efesiensi kerja pembuluh darah, jantung dan paru - paru . menurut Bompa kebugaran jasmani adalah kemampuan mengkonsumsi oksigen tertinggi selama kerja maksimal yang dinyatakan dalam liter/menit atau $\mathrm{ml} / \mathrm{kg} / \mathrm{mnt}$.

Hasil penelitian menunjukan bahwa siswa yang memiliki tingkat VO2Max pada kategeri baik, baik sekali,dan sempurna, sebagian besar yaitu $60 \%$ pada tingat kategori "cukup" dan $40 \%$ pada tingkat kategori "Kurang". Futsal merupakan kegiatan aktivitas olahraga yang sangat digemari untuk saat ini khususnya dikalangan laki-laki, dalam olahraga futsal tersendiri daya tahan aerobic atau VO2Max sangat di butuhkan. dalam memenuhi daya tahan seorang atlit harus mempunyai kapasitas energi dalam jumlah banyak. Tuntutan energy dalam jumlah banyak itu akan doproduksi dalam system aerobic yang memerlukan oksigen, oleh karna itu tinggi rendahnya daya tahan seorang pemain . tinggi rendahnya VO2Max para pemain sangat berpengaruh pada kondisi fisik atau kesegaran Jasmani.

\section{KESIMPULAN}

Berdasarkan hasil penelitian dan analisa data yang telah dilakukan. Peneliti dapat menark kesimpulan bahwa propil tingkat VO2Max siswa ektrakurikuler futsal SMAN 1 Parongpong secara umum berada dalam kategori "CUKUP" dengan rata-rata tingkat VO2Max adalah 36,83 $\mathrm{m} / \mathrm{kg} / \mathrm{min}$.dan perolehan secara rinci hasil penelitian sebagai berikut.

1. Sebagian besar siswa ektrakurikuler futsal SMAN 1 Parongpong berada pada kategori cukup dengan persentase sebesar $60 \%$ dimana nilai VO2Max tertinggi adalah $43,9 \mathrm{~m} / \mathrm{kg} / \mathrm{min}$.

2. Sebagian kecil siswa ektrakurikuler Futsal SMAN 1 Parongong berada dalam kategori kurang dengan persentase $40 \%$ dengan nilai VO2Max terendah adalah 27,6 . M/kg/min.

3. Tidak ada siswa ektrakuriler futsal SMAN 1 Parongpong dalam kategori Baik,Baik sekali,maupun kategori Sempurna.

\section{DAFTAR PUSTAKA}

Herita, w ramadhan. (2017). pengaruh latihan daya tahan.

M.Nazir Ph.D. (1997). No Title.

nurhasan. (2002). Tes dan pengukuran pendidikan olahraga. Padang: universitas andalas.

Suharjana. (2014). kebugaran jasmani. jogjakarta: Global Mandiri. 
Herita, w ramadhan. (2017). pengaruh latihan daya tahan.

M.Nazir Ph.D. (1997). No Title.

nurhasan. (2002). Tes dan pengukuran pendidikan olahraga. Padang: universitas andalas.

Suharjana. (2014). kebugaranjasmani. jogjakarta: Global Mandiri. 